УДК 373.3.091.33:004.021

DOI:

Іван Василиків, кандидат педагогічних наук, старший викладач кафедри математики, інформатики та методики їх викладання у початковій иколі Дрогобицького державного педагогічного університету імені Івана Франка Роксолана Романчук, магістр факультету початкової та мистецької освіти Дрогобицького державного педагогічного університету імені Івана Франка

\title{
ОСОБЛИВОСТІ ФОРМУВАННЯ АЛГОРИТМІЧНОГО МИСЛЕННЯ МОЛОДШИХ ШКОЛЯРІВ НА УРОКАХ ІНФОРМАТИКИ
}

У статті зосереджено увагу на основних методологічних підходах, щзо формують алгоритмічне мислення учнів початкової школи. На основі аналізу програми визначено актуальні підручники з інформатики, окреслено основні етапи розвитку алгоритмічного мислення молодиих школярів: елементи мови навчального алгоритму; впровадження практичної системи (виявлення помилок, відтворення, заміна, проєктування, перетворення алгоритмів з різними структурами з однієї форми в іншу). Водночас автор закликає уникати формалізму, спиратися на життєвий досвід учнів початкової школи, використовувати ігрові технологї та найкращуе поєднувати їх з інформаційними. Цей метод дасть кожній дитині можливість розкрити свої здібності та підготуватися до життя у конкурентному світі інформаційних технологій.

Ключові слова: початкова школа; алгоритмічне мислення; інформаційні технології.

Puc. 1. Jim. 9.

Ivan Vasylykiv, Ph.D.(Pedagogy), Senior Lecturer of the Mathematics, Informatics and Methods of Teaching in Primary School Department Drohobych Ivan Franko State Pedagogical University Roksolana Romanchuk, Master of the Faculty of Primary and Art Education Drohobych Ivan Franko State Pedagogical University

\section{THE PECULARITIES OF FORMATION OF ALGORITHMIC THINKING OF JUNIOR SCHOOLCHILDREN IN INFORMATICS LESSONS}

This article focuses on the main methodological approaches that shape the algorithmic thinking of primary school students. The authors, based on the analysis of the program, identified the current textbooks in computer science and the main stages of development of algorithmic thinking of junior schoolchildren: elements of the language of the educational algorithm; an introduction of a practical system (error detection, reproduction, replacement, design, transformation of algorithms with different structures from one form to another). At the same time, the authors urge to avoid formalism, rely on the life experiences of primary school students, and use game technologies and their best combination with information technology. This method will help each child to have the opportunity to discover their abilities and prepare for life in the competitive world of information technology. Many algorithmic operations require personal hygiene, all types of safety and general safety rules. The more "smart" devices we use in our daily lives, the more algorithms we teach our children. Therefore, children who already have a natural thinking algorithm, go to school. Children already know how to do many things on their own based on algorithms formed by natural needs, understand the mandatory sequence of certain actions and can verbally develop some of these actions.

The activity dimension of subject ICT competence is related to the algorithmic abilities of primary school students, such as formulating commands for performers, compiling algorithms based on samples, finding errors in sequence of commands and analyzing the content of the task for formulating algorithms. The performer looks for different options for the task, chooses and proves the most effective choice; distinguishes the structure of the algorithm: sequence, cycle; creates and executes an algorithm in a specific environment; distinguishes between correct and incorrect statements and adheres to statements with logic.

The solution to the problem of interest of primary school students who use a computer from preschool age and who are seriously engaged into computer science can be based on the use of Scratch programming language in teaching computer science.

Keywords: primary school; algorithmic abilities; informational technologies.

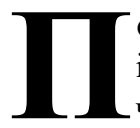
остановка проблеми. Сьогодні інформатизація $\epsilon$ характерним чинником людського життя, a особливо їі роль у більшості галузей сучасного життя України, оскільки сучасні інформаційні технології зовсім скоро стануть головним соціально-економічним фактором. Вивчення учнями початкових класів інформатики, стало 
вимогою часу, оскільки в цьому віці у них сформувався характерний спосіб мислення. Одним із завдань, пов'язаних 3 вивченням інформатики в початковій школі, є виховання в учнів здатності до алгоритмічного мислення.

Аналіз попередніх досліджень і публікацій. Багато вітчизняних вчених студіювали проблеми, пов'язані $з$ формуванням алгоритмічного мислення учнів початкових класів у процесі вивчення інформатики, зокрема,М.Гладун,О.Савченко, Н. Стрілецька. Поняття “алгоритмічне мислення" досліджували Я. Грудьонов, Т. Губіна, А. Єршов, Г. Звенигородський, Г. Лебедєв, Т. Лебедєва, А. Кушніренко та ін. Однак існує велика кількість проблем, пов'язаних з формуванням алгоритмічного мислення серед учнів початкової школи на уроках інформатики, які вивчені не до кінця. Враховуючи їх актуальність, ми обрали тему пропонованої статті.

Мета дослідження - розглянути питання, пов'язані 3 формуванням алгоритмічного мислення під час вивчення інформатики в початковій школі.

Виклад основного матеріалу. Мислення $\epsilon$ непрямим і універсальним відображенням дійсності, різновидом розумової діяльності, воно містить розуміння природи, речей і явищ, природних зв'язків та взаємозв'язків між ними [2]. Механізми мислення та фонетики нероздільні, особливо фонетичні слух і голосові дії. Мислення також невіддільне від практичної діяльності людей. Будь-яка діяльність повинна базуватися на рефлексії та враховувати умови дій, плану і спостереження. Практична діяльність $є$ головною умовою генерування та розвитку ідей, а також виступає еталоном істинності ідей. Оскільки мислення - це найвище пізнання людиною дійсності, сенсорну основу становлять почуття, сприйняття та уява. Це єдині канали для зв'язку між людським тілом та навколишнім світом. Інформаційний вміст із навколишнього середовища обробляється мозком. Найскладнішою формою обробки інформації та її трансформації $\epsilon$ мисленнєва діяльність. Розв'язуючи духовні проблеми, можна зробити висновки, тим самим дізнаючись суть речей і явищ, відкривши закони зв'язку між речами і явищами, а потім вносячи зміни на цій основі. Мислення людини не тільки тісно пов'язане з почуттям і сприйняттям, але й формується через них. Перехід від почуття до думки є складним процесом [3]. Мислення головний аспект розв'язання проблем, які постійно виникають у житті. Подолання проблем завжди має дати людині якісь нові знання. У процесі розвитку та формування особистості дитини найважливішим періодом є здобуття освіти, яку вона здобула в початковій школі. У цей час закладаються основи інтелектуального розвитку молодших школярів, створюються передумови для підготовки до самомислення, критичної оцінки ї поведінки, вміння порівнювати, висувати передумови для розв'язання проблем, оцінки та вибору більшість методів. Потрібно бути раціональними, виділяти і робити висновки, застосовувати знання на практиці. Необхідною умовою отримання таких результатів $є$ розвиток математичного мислення учнів початкової школи, що виступає найважливішим фактором для подальшого отримання освіти в школі та досягнення успіхів у навчанні та житті. Для молодших школярів найважливішим видом діяльності є освіта. Під керівництвом учителя вони виконують певні необхідні тренувальні вправи для засвоєння нових навичок. Молодші школярі вивчають матеріали двома способами: завдяки пам'яті та виконанню певних типів завдань. Рівень розвитку математичного мислення залежить від здатності вчителя формувати послідовну розумову операцію серед учнів. Учителі вибирають вправи та завдання, спрямовані на розвиток математичного мислення учнів початкової школи. Ці фактори можна використовувати в навчальній програмі та розуміти поняття “математичні операції та “математичні форми мислення”. При розв’язуванні завдань мислення учнів є найбільш очевидним. Адже в будь-якій задачі математичне мислення має великі можливості для розвитку. Математика допомагає учням здійснювати навчання 3 наукового мислення, оскільки це одна 3 теоретичних наук шкільної освіти. Тут найбільш природним способом вираження знань $є$ перехід від абстрактного до конкретного. Головне завдання вчителя - навчити учнів початкової школи правильно мислити. Під правильним математичним мисленням Л. Дашевська розуміє тип мислення якому притаманні:

- певність і ясність;

- послідовність;

- достовірність і доказовість [5, 269].

Зазвичай говорячи про розвиток мислення в процесі навчання математики, його зводять до розвитку математичного мислення. Звичайно, це правильно, оскільки в процесі навчання математики розвиток мислення переважно взагалі не розглядається, наприклад, конкретного математичного мислення. Питання у тому, що означає математичне мислення та яка його особливість. Ми провели дослідження, щоб повністю розглянути це питання. Для вивчення 


\section{ОСОБЛИВОСТІ ФОРМУВАННЯ АЛГОРИТМІЧНОГО МИСЛЕННЯ МОЛОДШИХ ШКОЛЯРІВ НА УРОКАХ ІНФОРМАТИКИ}

гнучкості математичного мислення було обрано техніку, що передбачає розв'язування логічних задач. Формування операційної структури мислення - це поєднання правил, що використовуються для розв'язання певних видів проблем у структурі розумової діяльності в системі зв'язків, що визначає її походження. Передовсім - реалізація об'єкта, проблеми та атрибутів об'єкта, що визначають принцип подолання проблеми. У корі головного мозку створюється готовий автоматичний механізм, який “працює” і виконує всі необхідні дії відразу після отримання відповідних вихідних даних та завдань для їх вирішення “не замислюючись”. Ця система механізмів для розв'язання певних типів проблем становить операційну структуру мислення. Функція проповідування, сформована алгоритмічним мисленням, О. Рибалко [8] вважає, що опорою оперативного мислення є такі навички та вміння:

- планувати послідовність операцій (етапів), які необхідно виконати для досягнення мети;

- виділити та описати атрибути будь-якого предмета;

- інформація, необхідна для організації пошуку шляхів розв'язання проблеми;

- чітко дотримуватися правил оперування об'єктом;

- свідомо користуватися клавіатурою обчислювального пристрою.

О. Воробей [4] підтверджує ту саму думку, та виокремлюючи водночас здатність алгоритмічного мислення представляти складні дії в певній послідовності більш простих дій. Т. Барболіна виділила такі компоненти алгоритмічного мислення:

- здатність аналізувати необхідні результати та робити вибір на основі вихідних даних для розв'язання проблеми;

- призначити основні операції, необхідні для визначення завдання;

- вибрати виконавців, які можуть виконувати ці операції;

- спростити операції та встановити модель рішення;

- реалізація рішення та відношення до результату, який слід отримати [1].

Для загальновизнаного значення поняття “алгоритмічне мислення” (включаючи мислення за зразком, що базується на заданих правилах, загальну послідовність дій, необхідних для розв'язання типових проблем), ми рекомендуємо включати мислення, яке спрямоване на встановлення цих правил та певних послідовностей. Вибрати систему стримування (обмежитися межами вибраної команди відповідного виконавця) і подумати над цим, щоб розробити план дій (алгоритм) у вибраній системі команд. Існує кілька способів формування алгоритмічного мислення людини: природний (який іноді в літературі називають мимовільним і спонтанним); освітній та соціальний (важливий).

У дитинстві людина вчиться: у сім'і, у повсякденному житті, у дитячому садку, у школі. Вчиться виконувати певні дії за певнимиалгоритмами на основі природнихалгоритмів, пов'язаних з певними природними ситуаціями. Наприклад:

I. Щоб підняти іграшку (залежно від місця іiі розташування), потрібно:

- поповзти, іти, досягати;

- покласти іï в долоню (залежно від розміру іграшки);

- тримати іграшку пальцями або обома руками.

II. Пити воду з чашки (для різного віку та здібностей учнів початкової школи), потрібно:

- помити чашку;

- налити воду (вода, необхідна - кип'ячена) тощо.

Багато алгоритмічних операцій вимагають дотримання особистої гігієни, усіх видів техніки безпеки та загальних правил безпеки. То більше “розумних” пристроїв ми використовуємо у своєму повсякденному житті, то більшій кількості алгоритмів навчаємо своїх дітей. Тому учнів початкової школи, які вже мають природне мислення за алгоритмом, ходять до школи. Учні початкової школи вже знають, як виконувати багато речей самостійно на основі алгоритмів, сформованих природними потребами, розуміють обов'язкову послідовність певних дій і можуть словесно розробити деякі з них. На основі цього вчителі початкових класів продовжують працювати $з$ дітьми [6].

Діяльнісний вимір предметної ІКТ компетентності пов'язаний 3 алгоритмічними здібностями учнів початкової школи, такими як формулювання команд для виконавців, складання алгоритмів на основі зразків, пошук помилок у послідовностях команд та аналіз змісту завдання для формулювання алгоритмів. Виконавець шукає різні варіанти завдання, вибирає та доводить найбільш ефективний вибір; розрізняє структуру алгоритму: послідовність, цикл; створює й виконує алгоритм у конкретному середовищі; розрізняє правильні та неправильні твердження i дотримується твердження 3 логікою. Протягом усього періоду навчання у початковій школі учні поступово засвоюватимуть ці ідеї та вміння через систему практики [7]. 


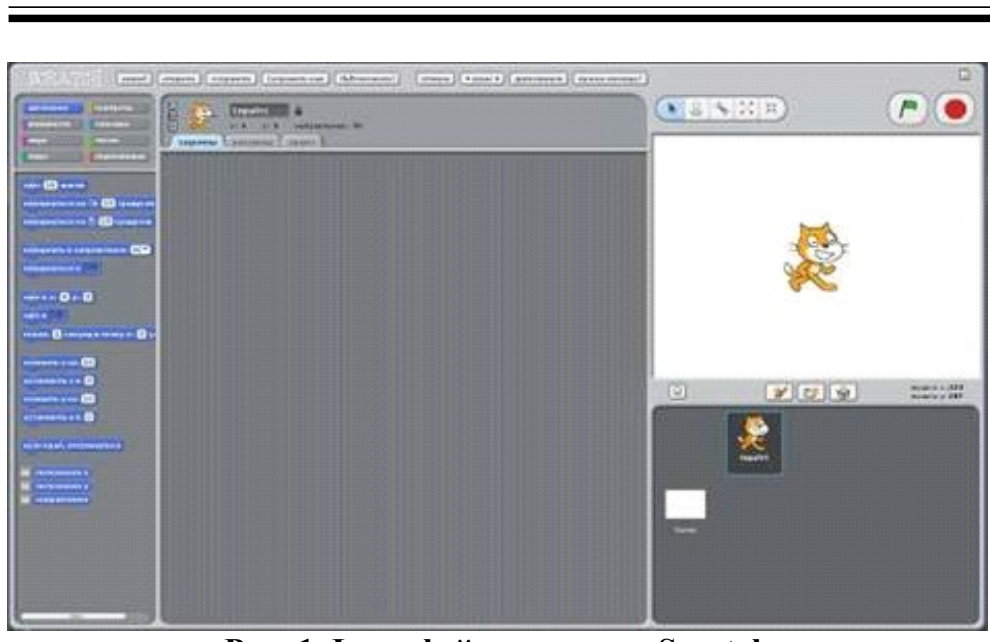

Рис. 1. Інтерфейс програми Scratch

різних умов, пересуватися по екрану та встановити об'єкти. Способи взаємодії один 3 одним. Діти можуть малювати й оживляти на екрані своїх героїв, а також навчитися користуватися графікою та звуками. Також важливо, що діти мають можливість ділитися результатами своєї роботи 3 друзями чи іншими користувачами. Для того, щоб діти ефективно здобували знання в новій галузі, вони повинні бути мотивованими. Якщо вони особисто зацікавлені

Процес формування алгоритмічного мислення молодших школярів здійснюється в такій послідовності:

1) ознайомлення учнів 3 певною структурою алгоритму;

2) введення елементів навчальної мови алгоритму;

3) реалізація системи вправ: виявлення помилок, відтворення, заміна.

Розв'язання проблеми зацікавлення учнів молодших класів, які використовують комп'ютер зі дошкільного віку та які серйозно займаються інформатикою, може базуватися на використанні у навчанні інформатики мови програмування Scratch.

Scratch - це об'єктно-орієнтоване середовище, в якому програмні блоки збираються 3 різнокольорових командних цеглин, подібно до того, як машини або інші об'єкти збираються 3 різнокольорових цеглин у конструкторі Lego. Крім того, можна знайти сучасні ідеї в середовищах візуального програмування (таких як Delphi) i навіть демонстраційних системах. Scratch мультимедійна система. Більшість операторів мови зосереджується на обробці графіки та звуку, створенні анімації і відеоефектів. Використовуючи шаблони зображень та звуку в наявній бібліотеці, створюючи власні файли та виконуючи операції 3 файлами проєктів (наприклад, зберігання, відкриття, створення), учні можуть швидко навчитися користуватися файловою системою та стандартними програмами. Scratch був розроблений як нове навчальне середовище для навчання учнів програмування. Водночас учні можуть легко використовувати свої здібності у фільмах, іграх, анімованих листівках та презентаціях, а також повною мірою реалізувати свої творчі таланти; винаходити та реалізовувати різні предмети, визначати їх зовнішній вигляд за в отриманні знань для досягнення своїх цілей, вони будуть мотивовані навчальною діяльністю. Програмне забезпечення, що розглядається, дає змогу створювати алгоритми, програми, проєкти, які безпосередньо цікавлять учнів початкової школи. Сприяти розвитку алгоритмічного мислення учнів початкової школи. Регулярне проведення уроку розвитку та організація цікавих завдань систематично створює сприятливі умови для формування таких цінних якостей, як алгоритмічне мислення і незалежність, що виявляється у активному пошуку рішень, глибокому й всебічному аналізі умов та критичних дискусіях.

Висновки. Отже, у статті проаналізовано основні шляхи розвитку алгоритмічного мислення на уроці інформатики. Розвиток навичок алгоритму поділяється на три етапи, які тісно пов'язані з розвитком логічного мислення. Водночас слід уникати формалізму, покладатися на життєвий досвід молодших школярів, використовувати ігрові технології, інтерактивні методи та оптимально поєднувати їх 3 інформаційними технологіями. Цей метод допоможе кожному молодшому школяреві мати можливість розкрити свої здібності та підготуватися до життя у конкурентному світі інформаційних технологій.

\section{ЛІТЕРАТУРА}

1. Барболіна Т. М. Розвиток алгоритмічного й операційного мислення у процесі вивчення прикладного програмного забезпечення. Комп 'ютер у школі та сім'ї. Київ, 2010. № 1. C. 19-22.

2. Білокобильська Н. Розвиток математичного мислення. Початкова освіта. 2000. № 41. С. 3.

3. Богданович М. В., Козак М. В., Король Я. А. Методика викладання математики у початкових 
класах: навч. пос., вид. 3, перероб. та доповн. Тернопіль, 2006. 336 с.

4. Воробей О. О. Викладання основ алгоритмізації у 5-му класі. Комп ютер у школі та сім'ї. 2013. №2. C. 7-9.

5. Дашевська Л.П. Способи навчальної роботи для розвитку математичного мислення школярів. Початкова школа. 1997. №6. С.11-14.

6. Кошелєв О. Пасічник Н. Теоретикометодичні основи розвитку алгоритмічного мислення молодших школярів. Молодь і ринок. 2017. № 8. C. 60-64. URL: http://nbuv.gov.ua/UJRN/ Mir $2017 \quad 8 \quad 13$

7. Навчальна програма для загальноосвітніх навчальних закладів 2-4 класів. Інформатика. URL: http://mon.gov.ua/activity/education/zagalnaserednya/pochatkova-shkola.html

8. Рибалко, О. О. Дидактична гра і навчання молодшого школяра. Комп'ютер у школі та сім' $\dddot{\imath}$ : науково-методичний журнал. 2011. №. 4. C. $26-30$.

\section{REFERENCES}

1. Barbolina, T.M.(2010). Rozvytok alhorytmichnoho y operatsiinoho myslennia $u$ protsesi vyvchennia prykladnoho prohramnoho zabezpechennia [The development of algorithmic and operational thinking in the process of studying an applied software]. Computer at school and family. Kyiv, No. 1. pp 19-22. [in Ukrainian].

2. Bilokobylska, N. (2000). Rozvytok matematychnoho myslennia [Development of mathematical thinking]. Primary education.No. 41. p. 3. [in Ukrainian].
3. Bohdanovych, M. V., Kozak, M. V. \& Korol, Ya. A. (2006). Metodyka vykladannia matematyky u pochatkovykh klasakh: navch. pos., vyd. 3, pererob. ta dopovn [The methods of teaching mathematics in primary school: a textbook. The $3^{\text {rd }}$ edition, supplemented and revised]. Ternopil, 336 p. [in Ukrainian].

4. Vorobe, O. O. (2013).Vykladannia osnov alhorytmizatsii u 5-mu klasi [Teaching the basics of algorithmization in the 5 th grade]. A computer at school and family. No. 2. pp. 7-9. [in Ukrainian].

5. Dashevska, L.P. (1997). Sposoby navchalnoi roboty dlia rozvytku matematychnoho myslennia shkoliariv [The methods of educational work for the development of mathematical thinking of students]. Elementary School. No.6. pp.11-14. [in Ukrainian].

6. Kosheliev, O. \& Pasichnyk, N. (2017). Teoretyko-metodychni osnovy rozvytku alhorytmichnoho myslennia molodshykh shkoliariv [The theoretical and methodological bases of development of algorithmic thinking of junior schoolchildren]. Youth and the market. No. 8. pp. 60-64. Available at: http:// nbuv.gov.ua/UJRN/Mir_2017_8_13[in Ukrainian].

7. Navchalna prohrama dia zahalnoosvitnikh navchalnykh zakladiv 2-4 klasiv [Curriculum for secondary schools 2-4 grades]. Informatics. Available at: URL: http://mon.gov.ua/activity/education/zagalnaserednya/pochatkova-shkola.html [in Ukrainian].

8. Rybalko, O. O. (2011). Dydaktychna hra i navchannia molodshoho shkoliara [Didactic game and teaching of the junior schoolboy]. Computer in school and family: scientific and methodical magazine. No. 4. pp. 26-30. [in Ukrainian].

Стаття надійшла до редакції 23.12.2020

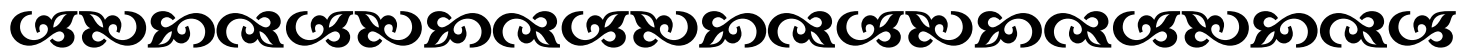
жuтmi”.

"Мислення - найдоблесніше заняття людини, найбільше блаженство і радість у Apicтотель
давньогрецький вчений-енциклопедист, білособ

"Коли людина мислить, вона має сумнів, але вона впевнена, коли діє”.

Анатоль Франи франиузький прозаїк

"Удосконалюватися - значить мінятися, бути досконалим - означає змінюватися часто".

Вінстон Үерчілль

державний діяч ВеликоїБританії, писъменник

\section{G5808nc20580}

